\title{
Dasybasis (Agelanius) cortesi, a New Species of Horse Fly from Chile (Diptera: Tabanidae: Diachlorini)
}

\author{
Christian R González ${ }^{+}$, Abel A Henry
}

Instituto Entomología, Universidad Metropolitana de Ciencias de la Educación, Casilla 147, Santiago, Chile

The female and male of Dasybasis (Agelanius) cortesi, new species, is described and illustrated from specimens collected in the National Reserve of Río Clarillo, Cordillera Province, Central Chile. Its relationships to other Dasybasis species are discussed.

Key words: Dasybasis (A.) cortesi n. sp. - Tabanidae - Neotropical region - Chile

The genus Dasybasis was erected by Macquart (1847) as a monotypic genus, including only the Australian species D. appendiculata.

This genus is characteristic of the southern temperate neotropical fauna with 82 taxa considered valid (Fairchild \& Burger 1994). Dasybasis also occurs in Australia and New Zealand, with 73 species described in two subgenera (Daniels 1989). It is very well represented in Chile (34 species) and Argentina (47 species). Dasybasis is the fourth largest genus of Tabanidae in the Neotropical region. Only Tabanus Linnaeus (165 species), Fidena Walker (120 species) and Stenotabanus Lutz (85 species) are larger. This genus present important variation in some characters as bare or rarely sparsely setose basicostas, extended dorsal angle on the basal flagellomere, shape of callus and many of the species are densely hairy, and most have medium (subgen. Agelanius Rond.) to very broad frons (Dasybasis s.str. and subgen. Haematopotina Cosc. \& Philip).

The Neotropical species of Dasybasis were monographed by Coscarón and Philip (1967a) who recognized five subgenera and 80 species. Coscarón (1969 a, 1972, 1989) has described additional species from Chile and Argentina. Only seven species are known from the immature stages (Coscarón 1969b, 1991, Coscarón \& Philip 1967b, Schwan 1989).

\section{MATERIALS AND METHODS}

The terminology follows that of Mc Alpine (1981). The frontal index is derived from the length

Work supported by Dirección Investigación, Univ. Metropolitana, Project IE 93-03

${ }^{+}$Corresponding author. Fax: +56-2-239.2067

Received 19 April 1996

Accepted 13 August 1996 of the frons divided by the basal width. The material examined were obtained from larvae collected from the National Reserve of Río Clarillo and maintained until adults emerged. In order to examine male and female genitalia, the abdomens were removed and macerated in hot $\mathrm{KOH}$ and posteriorly mounted on slides in Canadian balsam. Drawings were made with camera lucida.

Dasybasis (Agelanius) cortesi González n.sp. (Figs 1-11)

Description offemale - Length $12.5 \mathrm{~mm}$; wing 11 mm. Head: eyes dark brownish, without bands; with abundant gray hairs (Fig. 1). Front pale graybrown with grayish tomentum on the ocellar triangle, bearing black hairs. Front narrow, parallelsided, frontal index 4.0. Frontal callus black, with keel-shaped median projection more than half of the front; not touching eyes and subcallus (Fig. 2). Ocellar triangle with three ocelli. Posterior border of head gray; vertex with erect black hairs. Subcallus pale brown, tomentose, without hairs, darker near antenna. Clypeus and genae with gray pollinosity. Genae with short black hairs. Clypeus tomentose, with some black hairs only adjacent to antenna and lateral border. Beard with long gray hair. Scape of antenna with gray pollinosity and abundant short black hairs. Pedicel black, with grayish pollinosity; basal flagellomere black with light dorsal median angle and sparse gray pollinosity. Apical flagellomeres black (Fig. 3). Maxillary palpi with gray blackish pollinosity and short black hairs, slender and elongate (Fig. 4). Proboscis black; labellae black, large and fleshy.

Thorax - Mesoscutum dark gray with black and golden hairs, with longitudinal grayish pale narrow stripes reaching notopleural lobe. Notopleural lobe pale gray with long black and gray hairs. Scutellum dark gray, without pruinosity, with black-gray hairs that are longer than those on the 

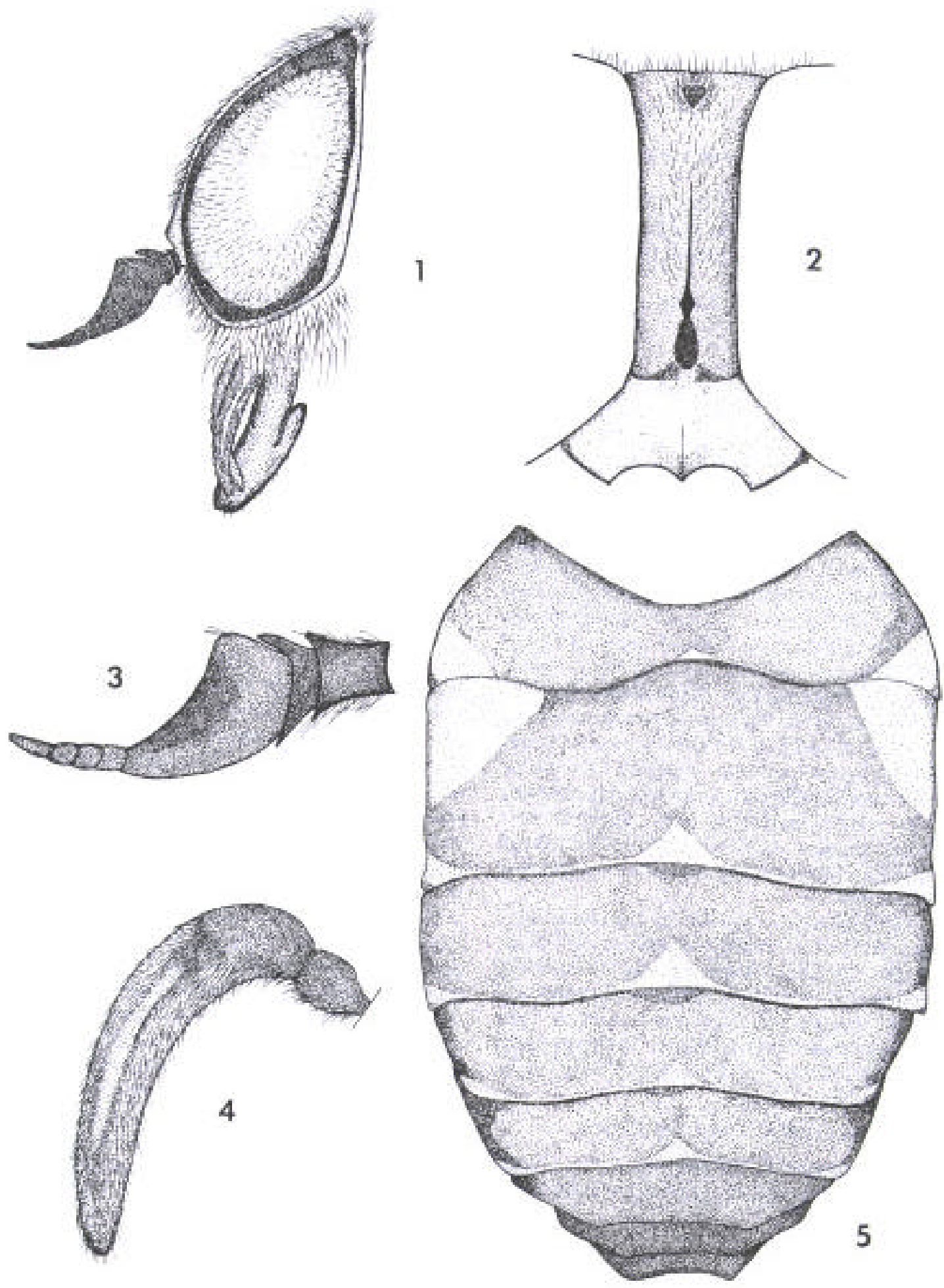

Dasybasis (Agelanius) cortesi n. sp. female. Fig. 1 : head in side view. Fig. 2: front. Fig. 3: antenna. Fig. 4: palp. Fig. 5: abdomen in dorsal view. 
mesoscutum. Pleura dark gray, with long blackgray hairs, only anepisternum and katepisternum with hairs more short. Legs dark brown. Coxae and femora with black-gray hairs; remaining leg segments with abundant short black hairs. Wing smoky with dark brown clouds on the veins and with short setae on Sc and R1; with short appendix on R4. Basicosta bare, apex acute. Halter dark brown. Squamae concolorous with base of wing. Abdomen - Dark brown dorsally, pale brown laterally on tergites I and II; posterior border of tergites with distinct narrow grayish pale hind margins and gray hairs, the gray hairs on posterior margins ex- panding into median triangles (Fig. 5). Sternites dark gray, mostly black haired.

Genitalia - Cerci subcircular with the apex semisharp, though internal border straighter than D.(A.) erebus Coscarón \& Philip; X tergite subsquare and with the tip semisharp well sclerotized (Fig. 6). Gonapophysis with border concave and lightly projected and with long hairs (Fig. 7). VIII sternite with wide base and long hairs (Fig. 7). Genital fork with wide base and long spermathecal ducts (Fig.8). Spermatheca distally acuminate, well scleorotized and with wide base (Fig. 9).
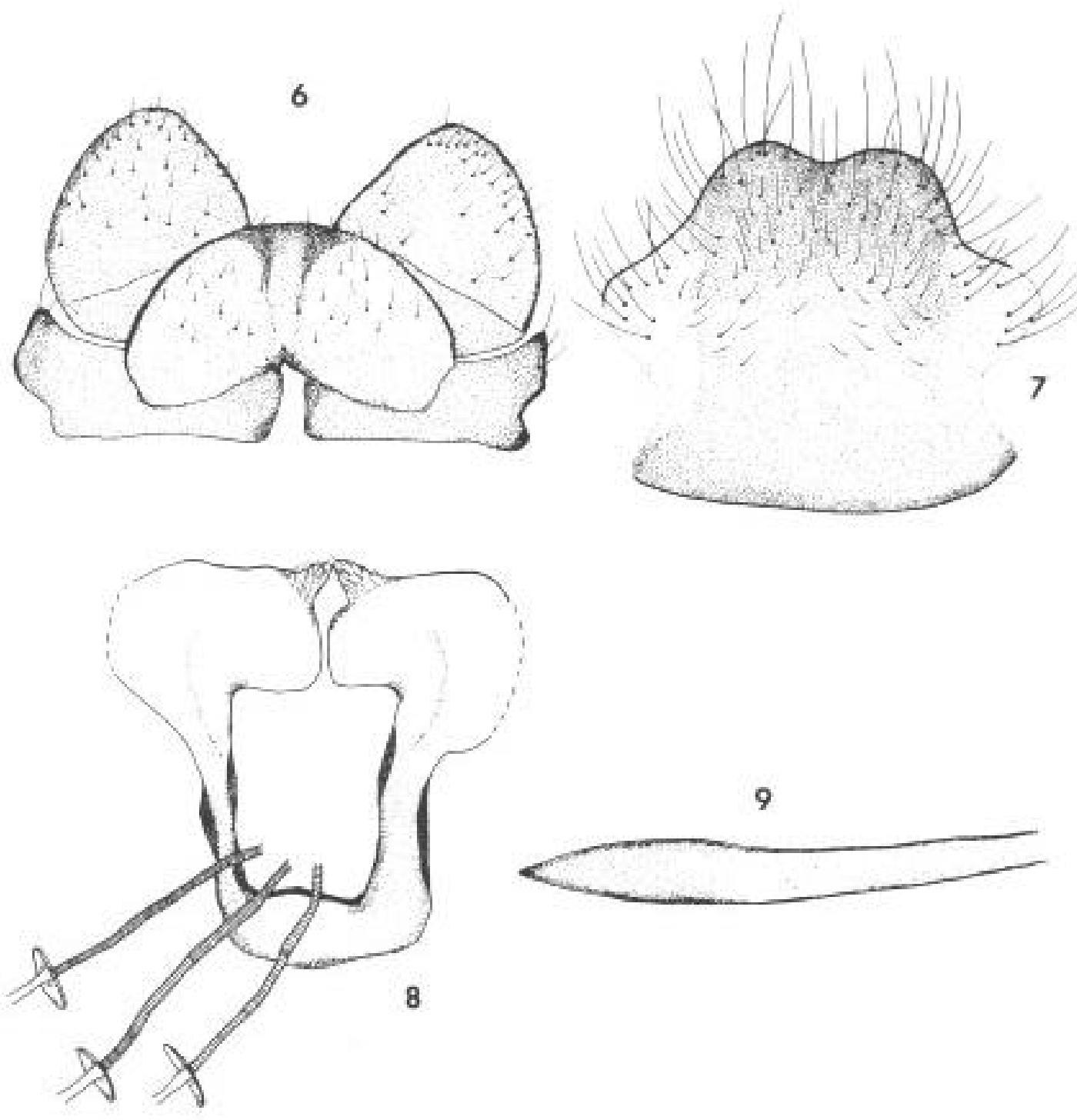

Dasybasis (Agelanius) cortesi $\mathrm{n}$. sp. female genitalia. Fig. 6: X tergite, cerci and hypoproct. Fig. 7: gonapophysis and VIII sternite. Fig. 8: genital fork and spermathecal ducts. Fig. 9: spermatheca. 
Description of male - Length $10 \mathrm{~mm}$; wing $10 \mathrm{~mm}$. Coloration similar to female except as follows: eyes with hairs more abundant than female; upper median eye facets large, clearly differentiated from lower facets; larger facetted areas pale brown; ocellar triangle present with three ocelli. Genae with dense, long gray hairs, and black hairs near eyes. Maxillary palpi pale brown with long gray hairs and more shorter. Thorax with longitudinal stripes diffuse; mostly long black haired but some short hairs at least anteriorly. Wing without appendix on R4 and clouds on the veins. Coxae with long gray hairs; femora with dense long black-gray hairs. Pleura gray, darker than female. Abdomen pale brown laterally on tergites I-III. Sternites II pale brown. Genitalia as in Figs 10 and 11.

Types - Holotype female, Chile, Cordillera Province, National Reserve of Río Clarillo, failure Los Almendros, 1.X.1992, CR González (Instituto Entomología, Univ. Metropolitana). Paratypes: 4E and $3 \mathrm{G}$, Cordillera Province, National Reserve of Río Clarillo, failure Los Almendros, 27.X.1992, CR González (1E and 1G Museo de La Plata, Argentina; 1E and $1 \mathrm{G}$ Department of Zoology, Univ. of New Hampshire, USA); 4E and $1 \mathrm{G}$ with same dates of Holotype in Instituto de Entomología, Univ. Metropolitana.

Etymology - This species is named in honor of $\mathrm{Dr}$
Raúl Cortés, a great dipterist and friend in recognition of his assistance and help in study of this family of Diptera.

\section{REMARKS}

This species exhibits generalized characters characteristics of the subgenus Agelanius Rondani: narrow front, ocellar triangle with three ocelli, basal flagellomere of the antenna with a dorsal median angle; maxillary palpi elongate. Dasybasis (A.) cortesi is very closely related to $D$.(A.) erebus Coscarón \& Philip in general appearance but $D$.(A.) cortesi differs on the following external characters: shape, width and extension of the frontal callus; wings clearer and with appendix on R4 (female), and clouds on the veins. Scutellum with golden hairs and general color of the body darker. In addition to gonapophysis are more excavated and genital fork with base longer than $D$.(A.) erebus Cosc. \& Philip. VIII sternite with wide base is similar to $D$.(A.) meridiana (Rond.) equally that gonapophysis but there are differences in general color of the body and basal flagellomere shape. X tergite semisharp, well sclerotized is similar to $D$. (A.) philippii (Rond.). D.(A.) aquila Cosc. \& Philip. show resemblance in callus and maxillary palpi shape in addition to a X tergite and cerci shape but shows differences in general color of the body, basal flagellomere and gonaphophysis shape.
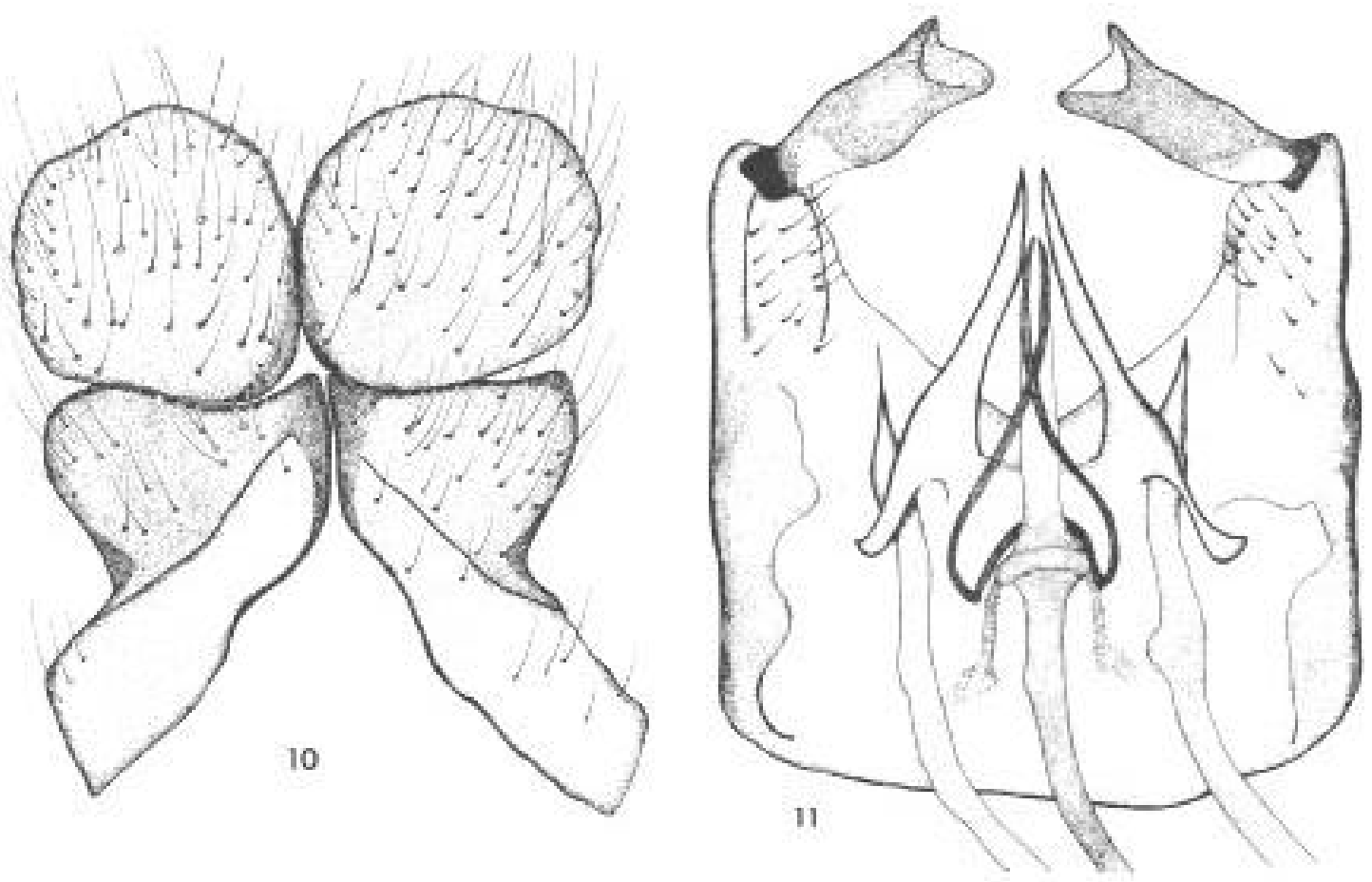

Dasybasis (Agelanius) cortesi n. sp. male genitalia. Fig. 10: X tergite and cerci. Fig. 11: gonocoxite, gonostyli and aedeagus. 


\section{ACKNOWLEDGEMENTS}

To Dr S Coscarón (Univ. Nac. La Plata, Argentina) for revision of manuscript and Dr JF Burger (Univ. of New Hampshire, USA) for his help in editing the English version. To CONAF (Corporación Nacional Forestal) for permission to carry out the research and to collect specimens in the National Reserve of Río Clarillo.

\section{REFERENCES}

Coscarón S 1969a. Notas sobre Tabánidos argentinos VIII. Dasybasis colla, una nueva especie de tábano hallada en la Puna Argentina. Neotropica XV: 115118.

Coscarón S 1969b. Datos sobre estados preimaginales de tábanos neotropicales (Diptera, Tabanidae). Rev Soc Ent Argentina 31: 19-22.

Coscarón S 1972. Datos adicionales sobre taxonomía y distribución del género Dasybasis (Macquart) en la Región Neotropical (Tabanidae, Diptera, Insecta). Rev Peruana Ent 15: 67-71.

Coscarón S 1989. A new species of Dasybasis Macquart from NW Argentina (Tabanidae, Diptera, Insecta). Mem Inst Oswaldo Cruz 84: 125-128.

Coscarón S 1991. Los estados inmaduros de siete especies neotropicales del género Dasybasis Macquart (Tabanidae, Diptera, Insecta). Acta Ent Chilena 16: 7-23.
Coscarón S, Philip CB 1967a. Revisión del género Dasybasis Macquart en la Región Neotropical (Diptera: Tabanidae). Rev Mus Argentino Cienc Nat Bernardino Rivadavia, Entomología 2: 15-266.

Coscarón S, Philip CB 1967b. Notas sobre biología y morfología de estadios preimaginales y descripción del macho de Dasybasis fairchildi Coscarón y Philip. Rev Soc Ent Argentina 29: 43-51.

Daniels G 1989. Family Tabanidae, p. 277-294 In NL Evenhuis, Catalog of the Diptera of the Australasian and Oceanian Regions. Honolulu and Leiden: Bishop Museum Press and EJ Brill.

Fairchild GB, Burger JF 1994. A Catalog of the Tabanidae (Diptera) of the Americas South of the United States. Mem Amer Ent Inst 55: 1-249.

Macquart J 1847. Diptères exotiques nouveaux ou peu connus 2e. supplément. Mem Soc Ry des Sci, de l' Agr et des Arts Lille 1846: 21-120, 6 plates.

Mc Alpine JF 1981. Morphology and terminologyadults, p. 9-63. In JF McAlpine, BV Peterson, GE Shewell, HJ Teskey, JR Vockeroth, DM Wood (eds). Manual of Nearctic Diptera 1. Research Branch, Agriculture Canada (Monograph No. 27).

Schwan EV 1989. Untersuchungen zum Vorkommen, zur biologie und zur bekampfung von Tabaniden (Diptera: Tabanidae) in der Provinz Valdivia, Chile. $\mathrm{PhD}$ Thesis, Tieraztliche Hochschule Hannover, 136 pp. 
